\title{
ORGANIZACINIS KLIMATAS LIGONINĖJE: DARBUOTOJŲ GRUPIŲ NUOMONE் (ATVEJO ANALIZĖ)
}

\author{
Vinsas Janušonis \\ Klaipèdos universitetas, Klaipédos universitetiné ligoniné
}

\begin{abstract}
Raktažodžiai: organizacinis klimatas, nesaugi darbo vieta, mobingas.

Santrauka

Nesaugios darbo vietos fenomenas yra sudetinga, sunkiai apibrèžiama, turinti daug vardų samprata. Saugaus organizacinio (psichologinio) klimato kūrimas yra sudètingas procesas, priklausantis nuo visų organizacijos darbuotojų. Darbo tikslas - įvertinti Klaipèdos universitetinès ligoninès organizacinị (psichologinị) klimatą ir ịvairių grandžiu vadovų poveikị jo formavimui darbuotojų požiūriu. Analizuotos ịvairių šalių autorių mokslinès publikacijos, apklausti darbuotojai. Atskleista darbuotojų, vertinusių organizacinị (psichologinị) klimatą ligoninèje, nuomonè bei ịvairių grandžių vadovų poveikis jị formuojant. Darbuotojų nuomone, organizacinis (psichologinis) klimatas ligoninejje yra pakankamai geras, ịvertintas gerokai aukščiau vidutinio, o įvairių grandžių vadovų darbas ir veikla, kuriant normalų organizacinị (psichologinį) klimatą ligoninèje, iš esmès vertinama gerai.
\end{abstract}

\section{Ivadas}

Nesaugios darbo vietos fenomenas mūsų šalyje pastaraisiais metais dažnai įvardijamas kaip mobingas, turintis daug apibrēžimų, sampratų, vardų, išraiškų bei priežasčių. Kiekvienas organizacijos darbuotojas ar vadovas gali būti šio fenomeno objektas ar subjektas. Sveikatos priežiūros organizacijos yra nesaugios darbo vietos, organizacinio streso didelès rizikos laukas, lemiamas veiklos specifikos - skubi ir neatidèliotina medicinos pagalba, didžiuliai krūviai, naktinis darbas, nuolatinis buvimas greta mirties, pacientų ir politikų spaudimas, - tai fonas, kuriame kinta darbuotojų elgsena. Kita vertus, reikalavimo atlikti darbą ir pareigas, vadovų reiklumo, aplaidumo netoleravimo, darbinio konflikto negalima vadinti mobingu. Plačiai paplitęs mobingas ịvairiuose socialiniuose tinkluose, daugiausiai ịvairiu grandžių vadovų atžvilgiu. Toks mobingas dèl savo didžiulès plètros ypač žalingas.
Darbo vietos saugumui labai svarbus normalus organizacinis (psichologinis) klimatas, visų darbuotojų, ypač vadovų, darbas ir veikla ji kuriant.

Darbo tikslas - jivertinti Klaipèdos universitetinès ligoninès organizacinị (psichologinị) klimatą ir ịvairių grandžių vadovų įtaką jo formavimui darbuotojų požiūriu.

\section{Literatūros apžvalga ir kontekstas}

Psichologiškai ir iš dalies fiziškai nesaugios darbo vietos fenomenas (NDVF) turi daug sampratų, apibrèžimų, vardų. Tai patyčios, priekabiavimas, psichologinis smurtas, psichologinis teroras, mobingas, agresija darbo vietoje, emocinis priekabiavimas ar smurtas, neproduktyvi elgsena darbe, užgaulus elgesys, psichologinè diskriminacija ir daug kitu. Tarptautinio bendro sutarimo ir bendros sampratos nèra [83,90,92,93-95].

Nesaugi darbo vieta veikia žmogaus gyvenimą, jo kokybę bei sveikatą. Darbo aplinka formuoja socialinius pokyčius, organizacinị, grupinị bei asmeninị identitetą. Nesaugi darbo vieta sveikatos priežiūroje yra visuotinè problema [1].

NDVF turi subjektą ir objektą bei jų sąveiką. Subjektas - tai žmogus, grupè ar organizacija, kurios poveikyje darbo vieta tampa nesaugi. Objektas - tai subjekto taikinys (kartais naudojamas terminas ,auka“), i kuri nukreiptas neigiamas subjekto poveikis.

NDVF subjektu ar objektu gali būti individas (vadovas, darbuotojas ar pacientas), žmonių grupè (profesinè, socialinè, amžiaus ar kt.), organizacija. NDVF iš dalies lemia subjekto ir objekto jègos disbalansas. Jis gali būti tarp to paties ar skirtingo rango darbuotojų (gydytojų ir slaugytojų, gydytojų ir rezidentų, vadovų ir pavaldinių).Tai labai sudètingas fenomenas, kurị nelengva suprasti ir dar sunkiau moksliškai ar teisiškai apibrèžti.

NDVF gali būti keturių tipų [2-4]:

- ịteigtas pašalinių asmenų, nesusietų su sveikatos priežiūros organizacija ir jos darbuotojais;

- raginamas trečios šalies asmenų, susietų su sveikatos priežiūros organizacija (pacientai, jų lankytojai, artimieji); 
- nulemtas bendradarbių tarpusavio santykių;

- kurstomas pašalinių asmenų, nesusietų su sveikatos priežiūros organizacija, bet susietų asmeniniais ryšiais su darbuotoju ar darbuotojais.

NDVF plinta tarp darbuotojų dažniausiai žodinès agresijos forma. Vis dèlto dažniausiai NDVF sąlygas sudaro pacientai ir jų artimieji. Apie tokius pažeidimus, ypač jei jie neturi fizinių pasekmių, dažniausiai nepranešama [5].

Daug patyčių, ypač dèl trečiosios šalies asmenų, patiria gydytojai, kartu jie yra daugelio patyčių subjektas [6,7], tačiau daugiausia patyčių patiria slaugytojai - tris kartus daugiau, nei kiti sveikatos priežiūros darbuotojai, įskaitant gydytojus [8].

NDVF neretai tapatinamas su blogu (nesveiku, nepatenkinamu) organizaciniu klimatu, o pastarasis - su psichologiniu klimatu bei darbuotojų pasitenkinimu darbu [9-13].

Organizacini (psichologinị) klimatą sudaro daugelis dedamujjų: organizacinès (organizacijos struktūra, charakteristikos, vadyba), procesinès (veiklos priežiūra, funkcijos, elgsena, veiklos kokybė), rezultatų (organizacijos darbuotojų pasitenkinimas, kaita, pacientų pasitenkinimas, klinikiniai rezultatai, sveikatos pokyčiai) ir daugelis kitu (darbuotojų lūkesčiai, autonomija, gerbūvis, parama, motyvacija) [1417]. Organizacinis (psichologinis) klimatas yra organizacijos veiklos ir darbinio proceso pamatinis pagrindas. Su tuo dauguma autorių sutinka, tačiau dèl minètų dedamųjų, jų poveikio organizacijos veiklai, elgsenai ir rezultatams, nuomonès skiriasi $[9,18-20,89]$. Vis dèlto organizacinio (psichologinio) klimato vertinimas yra svarbus kaip organizacijos veiklos, elgsenos, sveikatos priežiūros kokybès, darbuotojų ir pacientu pasitenkinimo, saugios darbo vietos, mobingo (patyčių) kontekstas. Ivairias organizacinio (psichologinio) klimato dedamąsias ir jị patị darbuotojai dažniausiai vertina vidutiniškai ir priklausomai nuo ju asmeninès sampratos. Būtina suprasti, kad organizacini (psichologinị) klimatą kiekvienas darbuotojas vertina pagal savo asmeninę sampratą, o ši samprata - labai skirtinga [20-23,97].

Mūsų šalyje pastaraisiais metais paplito NDVF pavadinimas - mobingas. Neretai moksliniuose tyrimuose mobingas yra patyčių sinonimas $[88,90]$. Terminas „mobingas“ vartojamas tik kai kuriose šalyse ir kai kurių mokslininkų, siekiant atskirti, kada neigiamą poveikị asmeniui daro grupe (mobingas), o kada asmuo (patyčios) [24]. Šis terminas, nurodomas kaip itališkas patyčių atitikmuo [25], dar naudojamas Lenkijoje, Vokietijoje ir Švedijoje. Būtina pabrěžti, kad grupè asmenų, kuri daro poveikị (mobingas), nèra atsitiktiniai asmenys organizacijoje. Tai gali būti padalinys, profesiné grupé (gydytojų, slaugytojų ar kt.), pareigybinė grupè (skyrių vedejjai ar kt.), amžiaus grupè (pensinio amžiaus ar kt.), lyties grupè (moterys ar vyrai), rasinè grupé, seksualinio pasirinkimo grupe ir kt. Pavieniai autoriai pažymi, kad mobingas gali būti ir tarp dviejų asmenų, tačiau tai būna retai [92]. Kartais objektu tampa visa organizacija - visos organizacijos mobingas gali būti tik sisteminis, kur subjektas yra steigejai, akcininkai, ministerija ir kitos valdžios ar įtakos grupès.

Patyčiu (mobingo) termino traktavimo, apibrèžimų, sinonimų yra įvairių, tačiau jų esmè - agresyvus elgesys, bendraujant tarpusavyje darbo vietoje. Tokiam elgesiui būdingas kartotinumas, ilga trukmè, objekto reakcija, jègos disbalansas, neadekvati parama objektui ar subjektui $[26,27,89,91]$.

Darbo aplinka turi tam tikrus ryšius su patyčiomis (mobingu). Pagrindiniai darbo aplinkos veiksniai, turintys įtakos NDVF ir jo padariniams [28-31]:

- vaidmenų konfliktas (pvz. siekis pakeisti vadovą ị palankų grupei asmenų);

- aukšti reikalavimai darbo atlikimui;

- didelè darbo veiklos kontrolè;

- nedalyvavimas sprendimų prièmime;

- pokyčiai ir reformos;

- rizika darbe (pvz. chirurginès operacijos, sunkios būklès ligonių priežiūra ir kt.);

- darbo paskirstymo ypatumai (pvz. budejjimai, operacijos ir kt.);

- igimtos žmonių savybès (pvz. elgsena, gyvensena ir kt.);

- darbuotojo norų ir galimybių neatitikimas;

- konkurencija tarp žmonių ir padalinių;

- blogas psichologinis klimatas padalinyje (dèl ịvairių priežasčių, tarp jų dèl vadovavimo padaliniui stiliaus);

- ekonominiai sukrètimai.

Daugelis autorių pažymi, kad saugios darbo vietos, saugaus organizacinio (psichologinio) klimato kūrime, kur labai svarbūs komunikacijos, komandinio darbo, teisingo šio proceso suvokimo veiksniai, svarbus vaidmuo tenka viduriniosios grandies vadovams [32-34]. Daug diskutuojama, kas daro ittaką NDVF - pavieniai individai ar organizacija ir sistema [35]. Vienu autorių nuomone, pirminès priežastys yra organizacijoje, nors daug kitu autorių $[3,36,95]$ neatmeta individualių veiksnių reikšmès ir svarbos. Rizikos veiksnių grupès mobingui (patyčioms) atsirasti gali būti tokios [4,37-39]:

- atskiri individai ar jų grupės:

- kaip subjektas;

- kaip objektas;

- situaciniai veiksniai (netinkama elgsena, konfliktai, ginčai ir kt.);

- aplinkos veiksniai;

- psichologinis (organizacinis) klimatas.

Organizacinis (psichologinis) klimatas organizacijoje yra 
ypač svarbus rizikos veiksnys, galintis lemti patyčias (mobingą) organizacijoje [37,40]. NDVF, nepriklausomai nuo objekto ir subjekto, gali būti organizacinio streso padarinys, tačiau kartu ji gali sukelti ar didinti. Sveikatos priežiūros organizacijos yra organizacinio ir individualaus streso didelès rizikos laukas. Tam sąlygas sudaro nuolatinis buvimas greta mirties, skubi ir neatidèliotina medicinos pagalba, nepageidautini įvykiai, didelis politikų, pacientų ir sistemos spaudimas. Visa tai labai didina NDVF riziką [41-45].

Sveikatos priežiūros organizacijose NDVF (mobingas, patyčios, priekabiavimas ir kt.) pasitaiko dažniausiai, palyginus su kitos veiklos organizacijomis - ji patiria beveik pusė darbuotojų $[3,46,47]$. Tiek pavaldūs darbuotojai, tiek vadovai skirtingai reaguoja ị patyčias (mobingą). Tai priklauso nuo jų asmeninių charakteristikų. Nuo šių charakteristikų priklauso ir skiriamoji riba - patyčios ar konfliktas darbe, darbo kontrole ir kt. Vertinant NDVF, visada reikia kartu vertinti galimą subjekto ar objekto psichikos sutrikimų įtaką šiam fenomenui, jo asmenines charakteristikas [24,48].

Dažniausia NDVF išraiška organizacijai - didelè neigiama personalo kaita, pravaikštos, blogi (blogejjantys) darbo veiklos rezultatai, maži (mažejantys) darbuotojų atlyginimai, daug nelaimingų atsitikimų darbe [27,49,50-53].

Mobinguotojai, dažniausiai grupe asmenų, visada turi lyderị. Šis lyderis neretai turi psichopatinių bruožų, nepamatuotų lyderiavimo ambicijų, pavydo kitų pasiekimams ir paděčiai.Mokslininkai atkreipia dèmesí, kad mobinguojami asmenys dažniausiai yra intravertai darbe, jiems darbas ir veikla sunkiau sekasi, jie labiau psichologiškai pažeidžiami, jautresni, emociškai nestabilūs $[25,54,55]$.

Mobingas gali pasireikšti grupès veiklos ar asmenų, jų savybių atžvilgiu. Jis gali būti aktyvus (tiesioginis) ir pasyvus (netiesioginis), horizontalus ir vertikalus. Mobingas atskirų grupių atžvilgiu gali pasireikšti nustatant per didelius ar per mažus darbo krūvius, netinkamus darbo grafikus, per didelę veiklos kontrolę, atsakomybę, informacijos teikimo ribojimą, finansavimą, aprūpinimą ištekliais ir kt. Kaip jau minèta, NDVF gali turèti labai daug panašių pavadinimų, nors sampratos skiriasi nežymiai ir esmès dažniausiai nekeičia. Tiek mobingo samprata, tiek jo pasireiškimas priklauso nuo šalies santvarkos, kultūros, istoriškai susiklosčiusių darbinių ir tarpusavio santykių, organizacijos kultūros, jos požiūrio ị NDVF, visų lygių vertybių sampratą, komunikacijos įpročius.

Minèti veiksniai formuoja darbinę aplinką, nuo kurios priklauso ir patyčių (mobingo) galimumas organizacijoje.

Mobingas apibrěžiamas kaip grupinis engimas, patyčių atmaina, tikslinis, sisteminis, ilgesnį laiką pasikartojantis elgesys kolektyvuose, kurio dažniausiais tikslas - paže- minti, išjuokti kuri nors narị, sumažinti jo vertę, atitolinti arba net atskirti nuo kolektyvo. Mobingo procesui būdingas veiksmas ir reakcija i ji - atoveiksmis.

Mobingas - tai priešiška, nedraugiška, neetinè komunikacija, vykdoma sistemiškai vieno ar grupès asmenų prieš vieną individą [56]. Būtina pažymèti, kad konfliktas, ypač darbinis, nèra mobingas ar patyčios.

Konfliktai darbe, ypač tarp vadovų ir pavaldinių, vyksta nuolat, konfliktų metu išsprendžiama daug problemų. Konfliktas iš esmès yra nuomonių nesutapimo ịvairiais klausimais padarinys.Konfliktai dažniausiai prasideda dèl priežasčių, susietų su konkrečiu individu (darbuotoju) dèl jo nepatenkintų poreikių, neišsipildžiusių lūkesčių, pavydo, negebèjimo ịvykdyti darbines užduotis, asmeninių charakteristikų $[57,58]$. Skirtingose šalyse patyčiu (mobingo) samprata yra nevienoda ir ju juridinis traktavimas skirtingas $[59,60]$. Kartais spaudimas siekti organizacijos tikslų ir intensyviau dirbti, didesnè darbuotojų darbo kontrole, didesni reikalavimai yra organizacijos politikos dalis, vadinama ,organizacine agresija“", neturinti nieko bendro su patyčiomis (mobingu). Tai pasireiškia vykdant didesnes reformas, struktūrinius organizacijų pokyčius $[61,62]$. Tik dažni, labai užsitęsę (610 mènesių), gilèjantys konfliktai, kurių priežastis darbinè veikla, gali peraugti ị sistemines patyčias. Juos dažniausiai formuoja nuolatinès reformos, kurios turi įtakos darbo vietos nestabilumui, profesiniam nepasitenkinimui, kelia organizacinį stresą. Sveikatos priežiūros organizacijose, kuriose didelè atsakomybė, pastovus bendravimas su žmonėmis, ribota darbuotojų autonomija priimant sprendimus, didelè darbo reglamentacija (normos, licencijos ir kt.), nuolatinis kontaktas su mirtimi, pacientų poreikių ir galimybių juos tenkinti neatitikimas labai didina organizacinio streso galimybę. Tiek nuolatiniai konfliktai, tiek organizacinis stresas, veikdamas individą priklausomai nuo jo tikslų, lūkesčių, požiūrių, sveikatos, emocinio stabilumo, gali peraugti ị patyčias arba būti individo traktuojamas kaip patyčios. Ypač palanki terpè konfliktams yra sveikatos priežiūros organizacijos dèl sveikatos priežiūros proceso dalyvių nepriklausomumo, intensyvių ir dauginių personalinių kontaktų, kontaktų tarp struktūrinių vienetų, didelio organizacinio streso, įtempto psichologinio klimato [63].

Konfliktai dažniausiai pasireiškia verbaline agresija, šiurkščiu nekultūringu elgesiu ir gali išsivystyti ị sistemines patyčias (mobingą). Būtina pažymèti, kad problemos būtent ir sprendžiasi, ịvykus konfliktui. Jis gali generuoti naujas idejjas, naujus iššūkius, pokyčius, todèl ne visada konfliktų reikia vengti.

Galimos konflikto šalys sveikatos priežiūros organizacijose :

- profesinès grupés (gydytojai, slaugytojai ir pan.); 
- skirtingo išsilavinimo grupès (slaugytojos su universitetiniu išsilavinimu ir be jo);

- skirtingos patirties grupès (vyresnio ir jaunesnio amžiaus medikai);

- skirtingų pareigybių grupès (vadovai ir darbuotojai);

- dirbantys skirtinguose padaliniuose (stacionare dirbantys gydytojai ir ambulatorijoje dirbantys slaugytojai);

- skirtingus atlyginimus gaunančių darbuotojų grupès.

Turint galvoje sveikatos priežiūros organizacijų veiklos sudètingumą, konfliktų ne visada galima išvengti, tačiau visada jiems galima daryti įtakos ir pakreipti teigiama linkme.

Mobingui sąlygas sudaro agresyvus elgesys, progresuojantis ir besitęsiantis ilgesnį laiką, bei tarpusavio santykių disbalansas. Agresyvus, mobinginis elgesys gali pasireikšti $[64,65]$ :

- pašiepimu (žmogaus drabužių, būdo, išvaizdos, ịpročiu ir kt.);

- atsiribojimu nuo objekto;

- gandų platinimu;

- informacijos neteikimu;

- drausminemis nuobaudomis ir pan. (kai subjektas vadovas);

- papildomais nereikalingais reikalavimais darbe;

- objekto kritika (ilgai trunkančia, nuolatine);

- priekabiavimu;

- fiziniais veiksmais.

Agresyvaus elgesio subjektas dažniausiai nesupranta, ką jis daro blogai kolegų, pavaldinio ar vadovo atžvilgiu, mano, kad viską daro teisingai ir nedaro nieko blogo [66]. Agresyvus elgesys, kaip ir mobingas, gali būti būdingas tiek subjektui, tiek objektui. Jeigu mobingą vykdo vadovaujantis darbuotojas (subjektas) prieš darbuotoją (dar vartojamas sinonimas „,bosingas“), tai dažniausiai jis vykdomas tiesiogiai, tiesioginio kontakto būdu, rečiau - virtualiai. Jeigu mobingas vykdomas darbuotojų prieš vadovą (sinstafingas), dažniausiai siekiant ji nušalinti ar pakeisti - čia jau pajungiama internetinè erdvè, socialiniai tinklai, e. laiškai, SMS žinutės ir kt. [67]. Kibernetinis mobingas ypač pavojingas - jis plinta greitai, aprépia didelę teritoriją, tiražuojamas, nuo jo sunku apsiginti. Toks mobingas paliečia mobingo objekto draugus, šeimą. Kibernetinis mobingas gali būti vykdomas vieno ar kelių asmenų, o sudaromas ịvaizdis, kad veikia daug žmonių ar net visa organizacija.

Mobingas - socialinis terminas, reiškiantis pasityčiojimą iš individo, vykdomas grupès žmonių - šeimos, socialinès grupès, mokinių, bendradarbių, kaimynų, bendruomenès tiesiogiai, per visuomenès informacijos priemones, ar virtualiai [68]. Pastaraisiais metais ypač plinta patyčios, dažniausiai anoniminès, virtualiuose portaluose, socialiniuose tinkluose (komentarai, postai ir kt.).
Patyčiu objektu darbo vietoje gali būti kiekvienas darbuotojas, nepriklausomai nuo jo užimamos pareigybès. Kai kuriuose tyrimuose pažymima, kad patyčių (mobingo) taikinys (objektas) dažniau būna darbuotojas, o subjektas ivairaus lygio vadovas [69], tačiau kiti mokslininkai pažymi, kad patyčių subjektu ar objektu gali būti maždaug per pusę: tiek vadovai, tiek kiti darbuotojai, arba darbuotojai gali tapti subjektu dažniau, nei vadovai $[3,67]$.

Tarp medicinos darbuotojų dažniau mobinguojami slaugytojai, o taip pat jauni, tik pradejję dirbti darbuotojai [69-71].

Gana plačiai paplitęs horizontalusis mobingas - tarp to paties lygmens darbuotojų [72,73].

Mobingo (patyčių) pasireiškimas susijęs ir su darbo vieta - mobingas dažniau pasireiškia operacinèse, intensyviosios terapijos ir prièmimo skyriuose $[48,74,75]$.

Mobingo priežastys gali būti įvairios [76-78]:

- subjekto problemos (asmens savybės, primityvumas, provincialumas, priklausymas grupei);

- objekto problemos (pavydas, elgsenos problemos, netinkamas požiūris ị pareigas ir atsakomybę, kompetencijos stoka, emociné būsena ir kt.);

- organizacinès priežastys (bloga vadyba, blogas organizacinis (psichologinis) klimatas, nepasitenkinimas darbu, aukšti reikalavimai darbui ir kt.);

- socialinès - kultūrinès priežastys (bloga, nesaugi aplinka, šeiminiai santykiai, teisinè sankloda ir kt.).

Sveikatos priežiūros organizacijose mobingas (patyčios) dažniausiai susijęs su organizaciniu (psichologiniu) klimatu, komunikacijos stoka, įvairiais neišsipildžiusių darbuotojų lūkesčiais, pareigų (vaidmenų) nesupratimu [6,79,80]. Darbuotojų tarpusavio santykiai, tarp jų ir mobingas (patyčios), labai glaudžiai siejasi su organizaciniu klimatu ir organizacijos veiklos rezultatais [16,22,45,81]. Mobingas (patyčios) yra vienas iš žalingos grupinès elgsenos komponentų, tam tikra diskriminacijos darbuotojų santykiuose forma.

Organizacinis (psichologinis) klimatas ir darbuotoju diskriminacija (patyčios, mobingas) susijusi su:

- darbo integracija ir tarpusavio priklausomybe;

- vadovavimo sritimi ir kokybe;

- komunikaciniais santykiais;

- personalo judejimu ir kaita;

- organizacijos narių saugumo jausmu;

- vertybių samprata;

- atsakomybès už darbą ir rezultatus suvokimu;

- darbo drausmès ir kontrolès būtinybès suvokimu;

- informacijos sklaida;

- motyvaciniais darbo veiklos veiksniais;

- personalinès ar grupinès elgsenos laisvès laipsniu organizacijoje;

- darbuotojų judejjimu ir kaita. 
Vertinant, ar tam tikrą reiškini galima traktuoti kaip mobingą (patyčias), reikia labai atsakingai ir atidžiai ịvertinti organizacinį, socialinį, profesinị ir individualų kontekstą, psichologinį klimatą, šių veiksnių integralų neigiamą poveiki, organizacinio ir grupinio klimato sąsajas organizacijoje [82-84]. Netinkamas organizacinis (psichologinis) klimatas sudaro prielaidas ịvairiems neigiamiems reiškiniams, tarp jų patyčioms sveikatos priežiūros organizacijoje, neigiamai veikia pacientų pasitenkinimą sveikatos priežiūra ir jos vertinimą $[85,96]$.

\section{Tyrimo objektas ir metodai}

Tirtuju kontingentas - Klaipèdos universitetinès ligoninès darbuotojai.

Tyrimo objektas - darbuotojų nuomonè apie psichologini klimatą ligonineje bei jos padaliniuose ir ịvairių lygių administracijos darbuotojų darbo ir veiklos vertinimas, kuriant normalų psichologinį klimatą, darbinę atmosferą, tarpusavio santykius ir santykius su pacientais.

Tyrimo metodai - literatūros analizè, verifikuota anoniminé anketiné apklausa, statistinè ir lyginamoji analizè. Tyrimui atlikti naudota anoniminé anketa pagal autoriaus parengtą klausimyną. Klausimyną sudaro 10 uždaro tirpo klausimų. Tyrimas vykdytas 2019 m. lapkričio 1 d. - 2020 $\mathrm{m}$. vasario 28 dieną. Tiriamųjų atsakymai vertinti penkių balų skalèje (5 - labai gerai, 4 - gerai, 3 - vidutiniškai, 2 patenkinamai, 1 - blogai).

Analizuoti ir lyginti ịvairių darbuotojų grupių tyrimo duomenys: medikų (gydytojų ir slaugytojų); kitų darbuotojų ne medikų, mišrios grupės; vadovaujančių darbuotojų (skyrių vedẻjų ir vyr. slaugos administratorių). Išdalintos 509 anketos, gautos užpildytos 504 (atsako dažnis 99 proc.). Ivertinus

1 lentelè. Psichologinio klimato ir darbinès atmosferos vertinimas (darbuotojų nuomonè)

${ }^{x} 5$ balai (labai gerai), 4 balai (gerai), 3 balai (vidutiniškai), 2 balai (patenkinamai), 1 balas (blogai).

\begin{tabular}{|c|c|c|c|}
\hline \multirow[t]{2}{*}{ Darbuotojų grupės } & \multirow{2}{*}{$\begin{array}{l}\text { Abs.sk. } \\
(\mathrm{n}=504)\end{array}$} & \multicolumn{2}{|c|}{ Vertinimas balais ${ }^{x}$} \\
\hline & & $\begin{array}{l}\text { ligoni- } \\
\text { nès }\end{array}$ & $\begin{array}{c}\text { padalinio, } \\
\text { kuriame } \\
\text { dirba }\end{array}$ \\
\hline $\begin{array}{l}\text { Medikai (visi) } \\
\text { iš jų: }\end{array}$ & 322 & 3,63 & 3,75 \\
\hline gydytojai & 77 & 3,69 & 4,05 \\
\hline slaugytojai & 245 & 3,61 & 3,63 \\
\hline $\begin{array}{l}\text { jaunesnysis medicinos perso- } \\
\text { nalas }\end{array}$ & 68 & 3,10 & 3,80 \\
\hline Ūkio personalas & 54 & 3,80 & 3,03 \\
\hline $\begin{array}{l}\text { Ivairus personalas (darbuotojų } \\
\text { visuotinio susirinkimo atstovai) }\end{array}$ & 60 & 3,72 & 4,08 \\
\hline Visi & 504 & 3,63 & 3,72 \\
\hline
\end{tabular}

dirbančiujų skaičių ligoninèje, apklausa reprezentatyvi.

Statistinè duomenų analizè atlikta naudojant statistinio duomenų analizès paketo SPSS 23.0 versiją ir Excel 2016 programą. Duomenų skirtumas statistiškai reikšmingas, kai $\mathrm{p}<0,05$ (statistinio pasikliautinumo lygmuo 95 proc.).

Tyrimo apribojimai:

1. Tiriamiesiems papildomai nepaaiškinta saugaus psichologinio, organizacinio klimato sąvoka, todèl kiekvienas tiriamasis vadovavosi savo asmenine psichologinio (organizacinio) klimato samprata.

Saugaus psichologinio klimato vertinimas, remiantis vien tik asmenine nuomone, nèra visavertis, atspindi tam tikras tendencijas [90]. Tikslesniam ịvertinimui reikètų tirti pacientu vertinimus, organizacijos veiklos rezultatus, nepageidautinus įvykius, skundus, padekkas ir kt.

2. Organizacinio (psichologinio) klimato vertinimo metodikų yra labai daug ir ịvairių, todèl šis tyrimas nėra išsamus organizacinio (psichologinio) klimato vertinimas, o orientacinès gairès tolesniam ligoninès veiklos tobulinimui.

3. Tyrimas vykdytas po anonimo šmeižikiško skundo, išplatinto visuomenès informacijos priemonemis, dèl neva blogo psichologinio klimato ligonineje. Visa tai galimai atsiliepè darbuotojų vertinimui.

\section{Tyrimo rezultatai ir jų aptarimas}

Psichologinį klimatą ir darbinę atmosferą ligoninèje penkių balų skalèje (labai gerai - 5, gerai - 4, vidutiniškai - 3, patenkinamai - 2, blogai - 1) darbuotojai ịvertino kaip pakankamai gerai (3,63 balo). Psichologini klimatą ir darbinę atmosferą padalinio, kuriame patys dirba, dauguma darbuotojų vertino kiek geriau, nei visos organizacijos, tačiau statistiškai patikimo skirtumo nenustatyta. Ivairios darbuotojų grupès (1 lentelè) psichologini klimatą ligoninèje vertino panašiai, išskyrus jaunesniji medicinos personalą. Kalbantis

2 lentelè. Psichologinio klimato ir darbinès atmosferos vertinimas (padalinių vadovų nuomonè)

${ }^{x} 5$ balai (labai gerai), 4 balai (gerai), 3 balai (vidutiniškai), 2 balai (patenkinamai), 1 balas (blogai).

\begin{tabular}{|c|c|c|c|}
\hline \multirow[t]{2}{*}{ Padalinių vadovų grupès } & \multirow{2}{*}{$\begin{array}{l}\text { Abs.sk. } \\
(\mathrm{n}=169)\end{array}$} & \multicolumn{2}{|c|}{ Vertinimas balais $^{x}$} \\
\hline & & $\begin{array}{l}\text { ligoni- } \\
\text { nès }\end{array}$ & $\begin{array}{c}\text { padali- } \\
\text { nio, ku- } \\
\text { riame } \\
\text { dirba }\end{array}$ \\
\hline $\begin{array}{l}\text { Medicinos padalinių vadovai } \\
\text { (gydytojai) }\end{array}$ & 54 & 3,74 & 4,24 \\
\hline $\begin{array}{l}\text { Medicinos slaugos padaliniu } \\
\text { vadovai (slaugytojai) }\end{array}$ & 55 & 4,16 & 4,30 \\
\hline $\begin{array}{l}\text { Visụ ligoninès padalinių rinkti } \\
\text { atstovai (visuotinis susirinkimas) }\end{array}$ & 60 & 3,72 & 4,08 \\
\hline Visi & 169 & 3,87 & 4,21 \\
\hline
\end{tabular}


3 lentelè. Aukščiausiosios grandies vadovų veiklos, kuriant normalų psichologinị klimatą ir darbinę atmosferą, vertinimas (darbuotojų nuomone)

${ }^{x} 5$ balai (labai gerai), 4 balai (gerai), 3 balai (vidutiniškai), 2 balai (patenkinamai), 1 balas (blogai).

\begin{tabular}{|c|c|c|c|c|}
\hline \multirow{2}{*}{$\begin{array}{l}\text { Darbuotojų } \\
\text { grupės }\end{array}$} & \multirow[b]{2}{*}{$\begin{array}{l}\text { Abs.sk. } \\
(n=504)\end{array}$} & \multicolumn{3}{|c|}{ Vertinimas balais ${ }^{x}$} \\
\hline & & $\begin{array}{c}\text { vyriau- } \\
\text { siojo } \\
\text { gydytojo }\end{array}$ & $\begin{array}{c}\text { vyriau- } \\
\text { siojo } \\
\text { gydytojo } \\
\text { pavaduo- } \\
\text { tojų }\end{array}$ & $\begin{array}{c}\text { vyriau- } \\
\text { siujuu } \\
\text { slaugos } \\
\text { adminis- } \\
\text { tratorių }\end{array}$ \\
\hline $\begin{array}{l}\text { Medikai (visi) } \\
\text { Iš ju: }\end{array}$ & 322 & 4,13 & 3,70 & 3,15 \\
\hline gydytojai & 77 & 4,0 & 3,72 & 3,27 \\
\hline slaugytojai & 245 & 4,19 & 3,69 & 3,10 \\
\hline $\begin{array}{l}\text { jaunesnysis medi- } \\
\text { cinos personalas }\end{array}$ & 68 & 3,8 & 3,5 & 3,5 \\
\hline Ūkio personalas & 54 & 3,87 & 3,9 & 4,0 \\
\hline Ivairus personalas & 60 & 4,02 & 3,8 & 3,3 \\
\hline Visi & 504 & 4,02 & 3,73 & 3,49 \\
\hline
\end{tabular}

4 lentelè. Aukščiausios grandies vadovų veiklos, kuriant normalų psichologinị klimatą ir darbinę atmosferą, vertinimas (padalinių vadovų nuomonè)

${ }^{x} 5$ balai (labai gerai), 4 balai (gerai), 3 balai (vidutiniškai), 2 balai (patenkinamai), 1 balas (blogai).

\begin{tabular}{|l|c|c|c|c|}
\hline \multirow{2}{*}{$\begin{array}{l}\text { Padalinių vadovų } \\
\text { grupės }\end{array}$} & $\begin{array}{c}\text { Abs.sk. } \\
\text { (n=169) }\end{array}$ & $\begin{array}{c}\text { vyriau- } \\
\text { siojo } \\
\text { gydy- } \\
\text { tojo }\end{array}$ & $\begin{array}{c}\text { vyriau- } \\
\text { siojo } \\
\text { gydytojo } \\
\text { pavaduo- } \\
\text { tojų }\end{array}$ & $\begin{array}{c}\text { vyriau- } \\
\text { siųjų } \\
\text { slaugos } \\
\text { adminis- } \\
\text { tratorių }\end{array}$ \\
\hline $\begin{array}{l}\text { Medicininių padalinių } \\
\text { vadovai (gydytojai) }\end{array}$ & 54 & 4,11 & 3,85 & 3,4 \\
\hline $\begin{array}{l}\text { Medicininių slaugos } \\
\text { padalinių vadovai } \\
\text { (slaugytojai) }\end{array}$ & 55 & 4,70 & 4,41 & 4,50 \\
\hline $\begin{array}{l}\text { Visų ligoninės padali- } \\
\text { nių rinkti atstovai (vi- } \\
\text { suotinis susirinkimas) }\end{array}$ & 60 & 4,02 & 3,8 & 3,3 \\
\hline Visi & 169 & 4,28 & 4,02 & 3,73 \\
\hline
\end{tabular}

individualiai, šie darbuotojai nurodè pagrindinę tokio vertinimo priežastį - per mažą atlyginimą, nors tai tiesiogiai ir nesusiję su organizaciniu klimatu.

Toks vertinimas atitinka literatūros duomenis - sveikatos priežiūros organizacijų darbuotojai organizacinį (psichologinị) klimatą ir jo dedamąsias vertina vidutiniškai [86,87].

Analizuojant vadovaujančio personalo nuomonę, nustatyta, kad ligoninès ir padalinio, kuriame dirba, vadovai organizacinị klimatą vertina geriau, nei pavaldūs darbuotojai (2 lentelè).

Ligoninès visuotinio susirinkimo atstovai organizacini
5 lentelė. Viduriniosios grandies vadovų veiklos, kuriant normalų psichologinị klimatą ir darbinę atmosferą, vertinimas (darbuotojų nuomonè)

${ }^{x} 5$ balai (labai gerai), 4 balai (gerai), 3 balai (vidutiniškai), 2 balai (patenkinamai), 1 balas (blogai).

\begin{tabular}{|c|c|c|c|c|}
\hline \multirow[b]{2}{*}{ Darbuotojų grupès } & \multirow[b]{2}{*}{$\begin{array}{l}\text { Abs.sk. } \\
(\mathrm{n}=504)\end{array}$} & \multicolumn{3}{|c|}{ Vertinimas balais ${ }^{x}$} \\
\hline & & $\begin{array}{c}\text { depar- } \\
\text { tamento } \\
\text { (kli- } \\
\text { niku) } \\
\text { vadovų }\end{array}$ & \begin{tabular}{|l} 
skyrių \\
vedėjų
\end{tabular} & $\begin{array}{c}\text { padalinių } \\
\text { vyresniujju } \\
\text { ir vy- } \\
\text { riausiųu } \\
\text { slaugos } \\
\text { administra- } \\
\text { torių }\end{array}$ \\
\hline $\begin{array}{l}\text { Medikai (visi) } \\
\text { iš jų: }\end{array}$ & 322 & 3,94 & 3,94 & 3,82 \\
\hline gydytojai & 77 & 4,03 & 4,13 & 4,20 \\
\hline slaugytojai & 245 & 3,90 & 3,86 & 3,73 \\
\hline $\begin{array}{l}\text { jaunesnysis medici- } \\
\text { nos personalas }\end{array}$ & 68 & 3,70 & 4,10 & 4,10 \\
\hline Ūkio personalas & 54 & 4,10 & 4,10 & 4,13 \\
\hline $\begin{array}{l}\text { Ivairus personalas } \\
\text { (darbuotojų visuo- } \\
\text { tinio susirinkimo } \\
\text { atstovai) }\end{array}$ & 60 & 3,90 & 4,10 & 3,68 \\
\hline Visi & 504 & 3,91 & 4,06 & 4,04 \\
\hline
\end{tabular}

6 lentelė. Viduriniosios grandies vadovų veiklos, kuriant normalų psichologinị klimatą ir darbinę atmosferą, vertinimas (padalinių vadovu nuomonè)

x 5 balai (labai gerai), 4 balai (gerai), 3 balai (vidutiniškai), 2 balai (patenkinamai), 1 balas (blogai).

\begin{tabular}{|c|c|c|c|c|}
\hline \multirow[b]{2}{*}{$\begin{array}{l}\text { Padalinių vadovų } \\
\text { grupès }\end{array}$} & \multirow[b]{2}{*}{$\begin{array}{l}\text { Abs.sk. } \\
(\mathrm{n}=169)\end{array}$} & \multicolumn{3}{|c|}{ Vertinimas balais ${ }^{x}$} \\
\hline & & $\begin{array}{c}\text { depar- } \\
\text { tamento } \\
\text { vadovu }\end{array}$ & $\begin{array}{l}\text { skyriụ } \\
\text { vedėjų }\end{array}$ & $\begin{array}{c}\text { padalinių } \\
\text { vyresniųjų } \\
\text { ir vy- } \\
\text { riausiųjų } \\
\text { slaugos } \\
\text { administra- } \\
\text { torių }\end{array}$ \\
\hline $\begin{array}{l}\text { Medicininių pada- } \\
\text { linių vadovai (gy- } \\
\text { dytojai) }\end{array}$ & 54 & 3,7 & 4,05 & 4,06 \\
\hline $\begin{array}{l}\text { Medicininių slau- } \\
\text { gos padaliniu va- } \\
\text { dovai (slaugytojai) }\end{array}$ & 55 & 4,36 & 4,40 & 4,60 \\
\hline $\begin{array}{l}\text { Visų ligoninės pa- } \\
\text { dalinių rinkti at- } \\
\text { stovai (visuotinis } \\
\text { susirinkimas) } \\
\end{array}$ & 6 & 3,90 & 4,1 & 3,68 \\
\hline Visi & 169 & 3,99 & 4,18 & 4,11 \\
\hline
\end{tabular}

klimatą taip pat vertino pakankamai gerai $(3,72)$ balo. Padalinio, kuriame dirba, vadovai organizacini klimata vertino aukščiau, nei gerai. 
Analizuojant darbuotojų grupių darbo ir veiklos, kuriant normalų psichologinị klimatą, darbinę atmosferą, tarpusavio santykius ir santykius su pacientais vertinimą, tirtas dviejų grupių - aukščiausiosios (vyriausiasis gydytojas, jo pavaduotojai, vyriausieji ligoninès slaugos administratoriai) ir viduriniosios grandies (departamentų ir klinikų vadovai, skyrių vedejai ir skyrių vyresnieji (vyriausieji) slaugos administratoriai) vadovų veiklos vertinimas.

Darbuotojai vyriausiojo gydytojo veiklą ir darbą įvertino gerai (4,02 balo), pavaduotoju - pakankamai gerai (3,73 balo), vyriausiujų slaugos administratorių geriau nei vidutiniškai ( 3,49 balo) (3 lentelè).

Vyriausiojo gydytojo darbą ir veiklą geriau vertino medikai (gydytojai ir slaugytojai), nei jaunesnysis medicinos ir ūkio personalas. Pastarojo vertinimas, jų teigimu, susijęs su per mažais atlyginimais.

Vyriausiojo gydytojo pavaduotojų ir vyriausiųų ligoninès slaugos administratorių darbą ir veiklą darbuotojai vertino kiek mažesniu balu. Tai galimai susiję su dažnesniais jų darbiniais kontaktais su darbuotojais. Statistiškai patikimų skirtumų nenustatyta.

Aukščiausiosios grandies vadovų darbą ir veiklą viduriniosios grandies vadovai vertino aukštesniais balais, nei visi darbuotojai (4 lentelè). Geriausiai šios grandies vadovų veiklą vertino vyresnieji (vyriausieji) padalinių slaugos administratoriai, antroje vietoje nemedicininiu padalinių (skyrių) vedèjai ir trečioje - visuotinio susirinkimo atstovai. Tai atitinka literatūros duomenis - aukščiausiosios grandies vadovų darbą ir veiklą darbuotojai vertina aukštesniais balais, nei pavaldūs darbuotojai [12].

Viduriniosios grandies vadovų (departamentų ir klinikų vadovų, skyrių vedèjų, vyresniųjų (vyriausiųjų) slaugos administratorių) veiklą ir darbą, kuriant organizacinị klimatą, darbuotojai vertino gerai (5 lentelè). Statistiškai patikimo skirtumo tarp vertinimų nenustatyta.

Kiek žemesniu balu vyresniųjų slaugos administratorių darbą vertino slaugytojai $(3,73$ balo) ir visuotinio susirinkimo atstovai (3,68 balo).

Idomus vertinimas savo darbo ir veiklos, kuriant normalų organizacinị klimatą (6 lentelè).

Viduriniosios grandies vadovai savo darbą ir veiklą vertino pakankamai objektyviai - iš esmès gerai. Kiek aukštesniu balu savo darbą ir veiklą vertino vyresniosios (vyriausiosios) slaugos administratorès (4,6 balo).

Savo atstovaujamo padalinio darbuotojų veiklą ir darbą, kuriant normalų organizacinị klimatą, visos darbuotojų grupès vertino gerai $(4,14$ balo). Geriausiai padalinius, kuriuose dirba, vertino gydytojai $(4,37$ balo) ir ūkio personalas (4,33 balo), kiek mažesniu balu vertino visuotinio susirinkimo atstovai (4,2 balo), slaugytojai (3,97 balo) ir jaunesnysis medicinos personalas (3,9 balo).

Medicinos skyrių vedejai savo padalinių indèli, kuriant normalų organizacinį klimatą, vertino 4,2 balo, padalinių vyresniosios (vyriausiosios) slaugos administratorès $-4,5$ balo.

\section{Išvados}

1. Ligoninès ir jos padalinių organizacinis (psichologinis) klimatas ir darbinè atmosfera darbuotojų nuomone iš esmès yra gera arba normali.

2. İvairių grandžių vadovų indèlį, kuriant organizacinị (psichologinị) klimatą ligonineje, darbuotojai vertino gerai - aukštesniais balais vyriausiojo gydytojo, skyrių vedejjų ir vyriausiujų (vyresniųų) slaugos administratorių, kiek žemesniais - vyriausiojo gydytojo pavaduotojų ir ligoninès vyriausiujų slaugos administratorių.

3. Savo atstovaujamo padalinio veiklą, kuriant normalu organizacinị klimatą ligonineje, darbuotojai vertino gerais ar aukštesniais balais.

\section{Literatūra}

1. Ramacciati N, Ceccagnoli A, Addey B. Violence against nurses in the triage area: an Italian qualitative study. International Emergency Nursing 2015;23:274-280.

https://doi.org/10.1016/j.ienj.2015.02.004

2. Mc Phaul KM, Lipscomb IA. Workplace violence in health care: recognized but not regulated. Online Journal of Issues in Nursing 2004; 9:1-12.

3. European Agency for Safety and Health at Work. European Survey of Enterprises on New and Emerging Risks. Managing safety and health at work. Luxembourg: Publication Office in the EU, 2010.

4. Hamblin LE, Essenmacher L, Ager J, et al. Worker-to-worker violence in hospitals. Workplace Health and Safety 2016; 64:51-56.

https://doi.org/10.1177/2165079915608856

5. Occupational safety and health administration. Understanding the challenge. Workplace violence in healthcare. OSHA 2017.

6. Leever AM, Hulst MD, Berendsen AJ. Conflict and conflict management in the collaboration between nurses and physicians - a qualitative study. Journal of Interprofessional Care 2010; 24:612-624.

https://doi.org/10.3109/13561820903550762

7. Berlanda S, Pedrazza M, Fraizzoli M, et al. Addressing risks of violence against healthcare staff in emergency departments: the effects of job satisfaction and attachment style. Biomed Research International SI 2019.

https://doi.org/10.1155/2019/5430870

8. Roche MA, Diers D, Duffield C, Catling-Paull CJ. Violence forward nurses, the work environment, and patients outcomes. Journal of Nursing Scholarship 2010; 42:13-22. 
https://doi.org/10.1111/j.1547-5069.2009.01321.x

9. Shoemaker DR. The relationship between organizational climate in the hospital and RN satisfaction. 1997. http://scholarworks. gvsu.edu/theses.

10. Patterson MG, West MA, Shackleton VI, et al. Validating the organizational climate measure: links to managerial practices, productivity and innovation. Journal of Organizational Behavior 2005;26:379-408

https://doi.org/10.1002/job.312

11. James LR, Choi CC, Ko CH, et al. Organizational and psychological climate: a review of theory and research. European Journal of Work and Organizational Psychology 2008; 17:5-32. https://doi.org/10.1080/13594320701662550

12. Carlfjord S, Andersson A, Nilsen P. The importance of organizational climate and implementation strategy at the introduction of a new working tool in primary health care. Journal of Evaluation in Clinical Practice 2010;16:1326-1332. https://doi.org/10.1111/j.1365-2753.2009.01336.x

13. Berberoglu A. Impact of organizational climate on organizational commitment and perceived organizational performance: empirical evidence from public hospitals. BMC Health Services Research 2018;18:399-423. https://doi.org/10.1186/s12913-018-3149-z

14. Henriksen K, Battles JB, Marks ES, et al, eds. Advances in patient safety: from research to implementation. Concepts and methodology. Agency for Healthcare Research and Quality USA 2005

15. Dawson JF, Gonsalez -Roma V, Davis A. West MA. Organizational climate and climate strength in UK hospitals. European Journal of Work and Organizational Psychology 2008; 17:89-111.

https://doi.org/10.1080/13594320601046664

16. Janušonis V. Sveikatos apsaugos sistemos organizacijų valdymas. Klaipėda: S.Jokužio leidykla - spaustuvė, 2012.

17. Maus MC. Examining the relationship between organizational climate and organizational citizenship behaviors within hospitals. Walden Dissertations and Doctoral Studies. 5901. 2018. https://scholarworks.waldence.edn/dissertations/5901.

18. Vartia M. The sources of buyling: psychological work environment and organizational climate. European Journal of Work and Organizational Psychology 2008;5:203-214. https://doi.org/10.1080/13594329608414855

19. Thumin FJ, Thumin LJ. The measurement and interpretation of organizational climate. The Journal of Psychology 2011;14593-109.

https://doi.org/10.1080/00223980.2010.538754

20. Carlucci D, Schiuma G. Organizational climates performance driver: health care worker's perception in a large hospital. Journal of Health Management 2014. https://doi.org/10.1177/0972063414548561

21. Hunt B, Ivergard T. Organizational climate and workplace efficiency. Public Management Review 2007; 9:27-47. https://doi.org/10.1080/14719030600853501

22. Žukauskas P, Vveinhardt J. Mobbing diagnosis instrument: stages of construction, structure and connectedness of criteria. Journal of Business Economics and Management 2011; $12: 400-416$.

https://doi.org/10.3846/16111699.2011.575193

23. Pena-Suarez E, Muniz I, Campillo-Alvarez A, et al. Assessing organizational climate: psychometric properties of the CLIOR scale. Psicothema 2013; 25(1):137-144.

24. Hoel H, Vartia M. Bullying and sexual harassment of the workplace in public spaces, and in political life in the EU. Directorate General for Internal Policies of the Union. European Union 2018.

25. Nardella Ch, Deitinger P, Atello A. Organizational conditions facilitating the emergence of mobbing. Seguridad y Medio Ambientes 2010;30.

26. Aquino K, Than S. Workplace victimization: aggression from the targets' perspective. Annual Review of Psychology 2009;60:717-741.

https://doi.org/10.1146/annurev.psych.60.110707.163703

27. Einarsen S, Hoel H, Zapf D, Cooper CL, eds. Bullying and harassment in the workplace. Developments in Theory Research, and Practice. 2-nd edn. London: Taylor and Francis 2011. https://doi.org/10.1201/EBK1439804896

28. Andersen C.R. Conflicts during organizational change: destructive or constructive? Nordic Psychology 2006;58:215-231. https://doi.org/10.1027/1901-2276.58.3.215

29. Notelaers G, Dewitte H, Einarsen S. A job characteristics approach to explain workplace bullying. European Journal of Work and Organizational Psychology 2010;19:487-504. https://doi.org/10.1080/13594320903007620

30. Hauge LJ, Skogstad A, Einarsen S. Relationships between work environment and bullying. Work and Stress 2007;21: 220-242. https://doi.org/10.1080/02678370701705810

31. Privitere MR, ed. Workplace violence in mental and general healthcare setting. Sudbury, MA: Jones and Bartlett 2011.

32. Singer S, Lin S, Folwell A, Goaba D, Baker L. Relationship of safety climate and safety performance in hospitals. Health Services Research 2009;44:399-421. https://doi.org/10.1111/j.1475-6773.2008.00918.x

33. Clarke S. An integrative model of safety climate: linking psychological climate and work attitudes to individual safety outcomes using meta-analysis. Journal of Occupational and Organizational Psychology 2010;83:553-578. https://doi.org/10.1348/096317909X452122

34. Halligan M, Zecevic A. Safety culture in healthcare: a review of concepts, dimensions, measures and progress. British Medical Journal Quality and Safety 2011; 20:338-343. https://doi.org/10.1136/bmjqs.2010.040964

35. Leymann H. Leymann inventory of psychological terror. 
Karlskrona: Violen 1992.

36. Randal P. Adult bullying: perpetrators and victims. London: Routledge 1997.

37. Neal A, Griffin MA, Hart PC. The impact of organizational climate on safety climate and individual behavior. Safety Science 2000;34:99-109.

https://doi.org/10.1016/S0925-7535(00)00008-4

38. Gillespie GL, Gates DM, Miller M, Howard PK. Workplace violence in healthcare settings: risk factors and protective strategies. Rehabil Nurs 2010;35:177-184. https://doi.org/10.1002/j.2048-7940.2010.tb00045.x

39. Isaak V, Vashdi D, Bar-Noy D, et al. Enhancing the safety climate and reducing violence against staff in closed hospitals wards. Workplace Health and Safety 2017;65:409-416. https://doi.org/10.1177/2165079916672478

40. Arnetz J, Hamblin LE, Sudan S, Arnetz B. Organizational determinants of workplace violence against hospital workers. Journal of Occupational and Environmental medicine 2018;60:693-699.

https://doi.org/10.1097/JOM.0000000000001345

41. Escriba-Aguir V, Perez-Hoyos S. Psychological well-being and psychosocial work environment characteristics among emergency medical and nursing staff. Stress and Health 2007;23:153-160.

https://doi.org/10.1002/smi.1131

42. Franz S, Zeh A, Schablon A, et al. Aggression and violence against health care workers in Germany - a cross sectional retrospective survey. BMC Health Service Research 2010; 15:1-6. https://doi.org/10.1186/1472-6963-10-51

43. Ferri P, Silvestri M, Artoni C, et al. Workplace violence in different settings and among various health professionals in an Italian general hospitals; a cross-sectional study. Psychol Research behave management 2016;9:263-275.

https://doi.org/10.2147/PRBM.S114870

44. Wilson JL. An exploration of bullying behaviors in nursing: a review of the literature. British Journal of Nursing 2016;25:303-306. https://doi.org/10.12968/bjon.2016.25.6.303

45. Janušonis V. Organizacinė elgsena ir kokybė sveikatos priežiūroje: integracinė sisteminė apžvalga. Klaipėda: S.Jokužio leidykla-spaustuvè, 2017.

46. Kanppinen T, Hanhela R, Kandolin I, et al. Work and health and Finland 2009. Finish Institute of Occupational Health 2010.

47. Carden L, Boyd R. Workplace bullying utilizing a risk management framework to address bullying in the workplace. Southern Journal of Business Ethics 2013;3:1-11.

48. Arnetz IE, Ager J, Upfal MJ. Worker-on-worker violence among hospital employees. International Journal of Occupational and Environmental Health 2011;17:328-335. https://doi.org/10.1179/oeh.2011.17.4.328

49. Einarsen S, Hoel H, Zapf D, Cooper CL, eds. Bullying and emotional abuse in the work place: international perspectives in research and practice. London: Taylor and Francis 2003.

https://doi.org/10.4324/9780203278734

50. De Pedro MM, Sanchez MIS, Navarro MCS, Izquierdo MG. Workplace mobbing and effects on workers' health. The Spanish Journal of Psychology 2008;11:219-227.

https://doi.org/10.1017/S1138741600004261

51. EU-OSHA and Eurofund. Psychosocial risk in Europe: prevalence and strategies for prevention. Luxembourg: Office of the EU 2014.

52. Mills J, Hall CH. Workplace bullying-wat's changing? New Zealand: Human Resources 2014.

53. Arnetz JE, Neufcourt L, Sudan S, et al. Nurse - reported bullying and documented adverse events. Journal of Nursing Care Quality 2020;35:206-212. https://doi.org/10.1097/NCQ.0000000000000442

54. Coyne I, Smith-Lee Chong P, Seigne E, Randall P. Self and peer nominations of bullying: an analysis of incident rates, individual differences, and perceptions of the working environment. European Journal of Work and Organizational Psychology 2003;12:209-228.

https://doi.org/10.1080/13594320344000101

55. Vie LT, Glaso L, Einarsen S. Health outcomes and self-labeling as a victim of workplace bullying. Journal of Psychological Research 2011;70:37-43.

https://doi.org/10.1016/j.jpsychores.2010.06.007

56. Duffy M, Sperry L. Mobbing. New York: Oxford University Press 2013.

57. Stanford N. Organization design: the collaborative approach. Abington: Routledge 2005.

https://doi.org/10.1016/B978-0-7506-6367-0.50006-7

58. Jones L. The application of organizational conflict management: a mixed method exploration of conflict training ang perceptions of NHS managers. Doctoral thesis, Cardiff University 2016.

59. Adams A. Bullying at work: how to confront and overcome it. London: Virago Press 1997.

60. Vega G, Corner DR. Sticks and stones may break bones, but words can break your spirit: bullying in workplace. Journal of Business Ethics 2005;58:101-109. https://doi.org/10.1007/s10551-005-1422-7

61. Harvey M, Treadway D, Heames JT, Duke A. Bullying in the 21 st century global organization: an ethical perspective. Journal of Business Ethics 2009;85:27-40. https://doi.org/10.1007/s10551-008-9746-8

62. Katrinli A, Atabay G, Cangarli BG, Gunay G. Perceived effectiveness of bullying behaviors as organizational political tactics. 23nd annual International Association of Conflict Management Conference. Boston, Massachusetts 2010. https://doi.org/10.1037/e673512012-059

63. Guidroz AM, Wang M, Perez LM. Developing a model of source-specific interpersonal conflict in healthcare. Stress and Health 2012;28:69-79. 
https://doi.org/10.1002/smi.1405

64. De Dreu CKW, Gelfand MJ, eds. The psychology of conflict and conflict management in organizations. Hove: Psychology Press 2013.

65. Divincova A, Sivakova B. Mobbing at work place and its impact on employee performance. Human Resources Management and Ergonomics 2014;8:20-34.

66. Field EM. Strategies for surviving bullying at work. Australia: Australian Academic Press 2011.

67. Grewe I. Neue medien-gefahren und chancen. Hamburg: Diplomica Verlag 2012.

68. Davenport N, Schwartz RD, Elliot GP. Mobbing: emotional abuse in the American workplace. Iowa: Civil Society Publishing 2003.

69. Yildrim A, Yildrim D. Mobbing in the workplace by peers and mangers: mobbing experienced by nurses working in health care facilities in Turkey and its effect on nurses. Journal of Clinical Nursing 2007;16:1444-1453. https://doi.org/10.1111/j.1365-2702.2006.01814.x

70. Longo J. Bullying and the older nurse. Journal of Nursing Management 2013;7:950-955.

https://doi.org/10.1111/jonm.12173

71. Caristo JM, Clements PT. Let's stop eating our young. Nursing Critical Care 2019;14:45-48. https://doi.org/10.1097/01.CCN.0000565040.65898.01

72. Topa G, Moriano JA. Stress and nurses' horizontal mobbing: moderating effects of group identity and group support. Nursing Outlook 2013;61:e25-e31. https://doi.org/10.1016/j.outlook.2013.03.002

73. Bloom EM. Horizontal violence among nurses: experiences, responses, and job performance. Nursing Forum 2018;54:77-83. https://doi.org/10.1111/nuf.12300

74. Adams AMN, Chamberlain D, Giles TM. The perceived and experienced role of the nurse unit manager in supporting the wellbeing of intensive care unit nurse: an integrative literature review. Australian Critical Care. doi:10.1016/j. aucc.2018.06.003, 2018.

https://doi.org/10.1016/j.aucc.2018.06.003

75. Al-Ghabeech. Qattom H. Workplace bullying and its preventive measures and productivity among emergency department nurses. Israel Journal of Health Policy Research 2019;8:1-11. https://doi.org/10.1186/s13584-019-0314-8

76. Hoel H, Cooper C. Destructive conflict and bullying at work. Manchester: Scholl of Management UMIST 2000.

77. Davenport NZ, Schwartz RD, Elliot GB. Emotional abuse in the American workplace, 3-d ed. Ames, IA: Civil Society Publishing 2005.

78. Cogenli MZ, Barli O. The exposure of psychological violence (mobbing) in universities and an application to the academicians. Procedia-Social and Behavioral Sciences 2013; 93:1174-1178. https://doi.org/10.1016/j.sbspro.2013.10.010

79. Chipps E, Stelmaschuk S, Albert NM, et al. Workplace bullying in the OR: results of a descriptive study. AORN Journal 2013;98:479-493.

https://doi.org/10.1016/j.aorn.2013.08.015

80. Wright RR, Mohr CD, Sinclair RR. Conflict on the treatment floor: an investigation of interpersonal conflict experienced by nurses. Journal of Research in Nursing 2014;19:26-26. https://doi.org/10.1177/1744987113485577

81. Janušonis V. Rizikos valdymas sveikatos priežiūros organizacijose: sisteminè teorinè- praktinė apžvalga. Klaipėda: S.Jokužio leidykla-spaustuvè, 2016.

82. Hutchinson M, Wilkes L, Jackson D, Vickers MH. Integrating individual, work group and organizational factors: testing a multidimensional model of bullying in the nursing workplace. Journal of Nursing Management 2010;18:173-181. https://doi.org/10.1111/j.1365-2834.2009.01035.x

83. Janušonis $\mathrm{V}$. Tinkama sveikatos priežiūra: socialinio streso vaidmuo. Sveikatos mokslai, 2009;19:2451-2456.

84. Zohar D, Luria GA. Multilevel model of safety climate: cross level relationships between organization and group-level climates. Journal of Applied Psychology 2005;90:616-628. https://doi.org/10.1037/0021-9010.90.4.616

85. Ancarani A, DiMauro C, Giammanco MD. Patient satisfaction, managers' climate orientation and organizational climate. International Journal of Operations and Production Management 2011;31:224-250.

https://doi.org/10.1108/01443571111111900

86. Wienand U, Cinotti R, Nicoli A, Bisagni M. Evaluating the organizational climate in Italian public healthcare institution by means of a questionnaire. BMC Health Service Research 7 2007. http:/www.biomedcentral.com/1472-6963/7/73, https://doi.org/10.1186/1472-6963-7-73

87. Pena-Viveros R, Hernindez-Hernindez DM, Velez-Moreno AML, et al. Organizational climate in management teams and its relationship with health care outcomes. 2015. https://www. medigraphic.com.

88. Pumar-Mendez MJ, Attree M, Wakefield A. Methodological aspects in the assessment of safety culture in the hospital setting: a review of the literature. Nurse Education Today 2014; 34:162-170.

https://doi.org/10.1016/j.nedt.2013.08.008

89. Leymann H. The content and development of mobbing at work. European Journal of Work and Organizational Psychology 1986;5:165-184.

https://doi.org/10.1080/13594329608414853

90. Sperry L. Workplace mobbing and bullying: a consulting psychology perspective and overview. Consulting Psychology Journal Practice and Research 2009;61:165-168. https://doi.org/10.1037/a0016936

91. Sperry L, Duffy M. Workplace mobbing: family dynamics and therapeutic considerations. The American Journal of Family 
Therapy 2009;37:433-442.

https://doi.org/10.1080/01926180902945756

92. Crawshaw L. Work place bullying? Mobbing? Harrashment? Distraction by a thousand definitions. Consulting Psychological Journal: Practice and Research 2009;61:263-267.

https://doi.org/10.1037/a0016590

93. Etienne E. Exploring workplace bullying in nursing. Workplace Health Safety 2014; 62-6-11. https://doi.org/10.1177/216507991406200102

94. Longo J, Sherman RO. Leveling horizontal violence. Nursing Management 2007;38:34-37. https://doi.org/10.1097/01.NUMA.0000262925.77680.e0

95. Gillen PA, Sinclaire M, Kernohan WG, et al. Interventions for prevention of bullying in the workplace. Cochrane Database Syst Rev 2017;1(1):CD009778. https://doi.org/10.1002/14651858.CD009778.pub2

96. Shneider B, Ehrhart MG, Macey BWH. Organizational climate and culture. Annual Review of Psychology 2013;64:361-388. https://doi.org/10.1146/annurev-psych-113011-143809

97. Bowling NA, Beehr TA.Workplace harassment from the victim's perspective: a theoretical model and meta-analysis. Journal of Applied Psychology 2006;91:998-1012.

https://doi.org/10.1037/0021-9010.91.5.998

\section{ORGANIZATIONAL CLIMATE IN THE HOSPITAL: OPINION OF STAFF GROUPS (CARE STUDY) \\ V. Janušonis}

Keywords: organizational climate, unsafe work place, mobbing. Summary

The phenomenon of unsafe workplace is a complex, difficultto-define concept.

Aim of the research: To evaluate the opinion of Klaipeda uni- versity hospital employees about the organizational (psychological) climate in the hospital and the influence of various managers in its formation.

Research methodology. The research was performed in 20192020 by applying quantitative (questionnaire survey) research method.

Questionnaire survey was applied by questioning employees of four different groups: medics (doctors and nurses), executives, other employees, and mixed group of employees.

Questionnaires were completed by 504 employees. Statistical data analysis war prepared by using SPSS 23,0 statistical analysis packet and tables were prepared by using Microsoft Excel 2016.

Results. Assessing the opinion of health care workers, heads of different health care facilities and others workers, they assessed the psychological climate in the hospital similary - almost as good.

The psychological (organizational) climate in the unit in which employees work themselves they rated slightly Better, than the hospital.

Analyzing the influence of managers in creating and formation a normal psychological (organizational) climate in hospital, the employees assessed activity of head of hospital, heads of units, and senior nursing administrators as good. The influence of deputy's of head of hospital and chief-nurses of hospital the employees assessed a slightly lower score.

Conclusions. The organizational (psychological) climate and working atmosphere of the hospital and its departments are normal and good in the opinion of the staff.

The contribution of managers of various levels in creating and formation a normal climate of organization the employees assessed generally as good.

Correspondence to: janusonis@kul.lt

Gauta 2020-12-03 